Volume 45 | Issue 1

2012

\title{
A Tragi-Comedy of Errors Erodes Self-Execution of Treaties: Medellín v. Texas and Beyond
}

John Quigley

Follow this and additional works at: https://scholarlycommons.law.case.edu/jil

Cart of the International Law Commons

\section{Recommended Citation}

John Quigley, A Tragi-Comedy of Errors Erodes Self-Execution of Treaties: Medellín v. Texas and Beyond, 45 Case W. Res. J. Int'1 L. 403 (2012)

Available at: https://scholarlycommons.law.case.edu/jil/vol45/iss1/1

This Article is brought to you for free and open access by the Student Journals at Case Western Reserve University School of Law Scholarly Commons. It has been accepted for inclusion in Case Western Reserve Journal of International Law by an authorized administrator of Case Western Reserve University School of Law Scholarly Commons. 


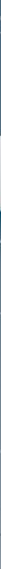

A Tragi-Comedy of Errors Erodes Self-Execution of Treaties: MEDELLÍN V. TEXAS AND BEYOND

\author{
John Quigley
}




\title{
A Tragi-Comedy of ERrors ERODES SELF-EXECUTION OF TReaties: MeDELLÍN V. TEXAS AND BEYOND
}

\author{
John Quigley*
}

The 2008 U.S. Supreme Court decision in Medellín v. Texas has generated concern that the doctrine of self-execution of treaties is being eviscerated. The Court's decision involved misapplication of that doctrine in a case in which self-execution should not have been center stage in the first place. The case should have turned on presidential power, not on selfexecution. The Court hinted at a new and stricter standard for finding treaty provisions to be self-executing. The Court purported to be acting consistent with its own precedents on standards for self-execution but analyzed the treaty provision at issue in a manner at odds with precedents, inappropriately concluding that it was not self-executing. In a series of cases arising since Medellín involving treaties as between private parties, the lower federal courts have, appropriately, disregarded the Medellín decision and have continued to apply treaties as required by the Supremacy Clause of the United States Constitution.

\section{CONTENTS}

I. Context of the Self-Execution Issue: Consular Access Claims.

II. The President Seeks Implementation of Avena ...................... 408

A. The Obligation to Review and Reconsider................................4 410

B. President Bush's Mode of Seeking Implementation.......................411

III. Self-Execution in the Supreme Court's Analysis ................... 413

IV. The Supreme Court's Reading of UN Charter Article 94......4 417

A. Enforcement Mechanism in UN Charter Article $94 \ldots \ldots \ldots \ldots \ldots \ldots \ldots . . . . . . . . .418$

B. ICJ Statute Articles 34(1) and Article $59 \ldots \ldots \ldots \ldots \ldots \ldots \ldots \ldots \ldots . \ldots . \ldots . \ldots . \ldots . \ldots . \ldots 1$

V. Conflict with Prior Self-Execution Decisions..................... 422

VI. Meaning of Medellín for Defensive Invocation of A TREATY

President's Club Professor in Law, Michael E. Moritz College of Law, The Ohio State University. The author is grateful to Professor Jean Galbraith for data on post-Medellin treaty drafting. He is grateful to colleagues at the Moritz College of Law for comments at a presentation on a draft of this article. 
ViI. Meaning of Medellin for Executive Enforcement of A TREATY

ViII. Declaration in a Senate Resolution of Consent

IX. The Supreme Court's Operational Rule ........................... 428

X. Treaties in Private Law Cases Post-Medellín.

Xi. Conclusion.

The unfortunate analysis of treaty self-execution given by the Supreme Court in Medellín v. Texas was the last in a series of missteps in the case. The prior missteps should have kept the case from reaching the Court. The Court itself then produced an opinion out of step with its own case law, without explaining, or perhaps even understanding, the extent to which it was undermining the traditional analysis of self-execution of treaties under the Supremacy Clause of the U.S. Constitution. The Court's errors are sufficiently egregious that it may not be unrealistic to anticipate that in future cases the analysis in Medellín v. Texas may be limited or ignored. This article, after analyzing Medellín $v$. Texas itself, traces post-Medellin cases in the lower courts.

Medellin $v$. Texas came out of more than a decade of litigation both in the United States and in international institutions relating to the access of foreign nationals under arrest to consular officials of their home country. The issue before the Court in Medellín v. Texas was the domestic enforceability of an international decision on that subject. This earlier consular access litigation set the stage for Medellín $v$. Texas, and it is with it that this article begins.

\section{Context of the Self-Execution Issue: Consular ACCESS Claims}

The context for Medellin $v$. Texas, though not the issues in dispute in the case itself, was consular access for foreign nationals accused of crime in the United States. Access to a consular official is provided for in the Vienna Convention on Consular Relations (VCCR), a multilateral treaty to which most states of the world are party. ${ }^{1}$ Authorities arresting a foreign national are required to inform the individual of a right to contact a consular office of the individual's home country. ${ }^{2}$ The reason for this procedure is to allow consular

1. Vienna Convention on Consular Relations, Apr. 24, 1963, 596 U.N.T.S. 261.

2. Id. art. 36 . 
officials to provide assistance during the pre-trial phase, the trial phrase if a trial occurs, and beyond. ${ }^{3}$

The legal issue that led ultimately to Medellin v. Texas was that of the legal consequences of the arresting authority's failure to inform a foreign national about consular access. Beginning in the mid-1990s, lawyers in the United States working through the Texas Resource Center took on the cases of a number of foreign nationals who had been convicted of murder in Texas and sentenced to death, but who had not been informed upon arrest about consular access. These lawyers argued that this failure required a remedy, like other procedural failures in criminal cases. ${ }^{4}$

Lawyers elsewhere in the United States followed suit. Some sought to suppress a pre-trial statement for failure to inform about consular access, filing a suppression motion pre-trial, or raising the issue on appeal..$^{5}$ Others challenged, post-trial, the imposition of capital punishment, on the theory that participation by a consul might have led to more solid evidence in mitigation. ${ }^{6}$ The Government of Mexico, which maintains an extensive network of consular offices in the United States, took an active role in supporting legal action on behalf of its nationals in these situations.

Results were mixed, both in the trial courts, and in courts hearing appeals or habeas corpus petitions of those already convicted. In most instances, the courts denied relief. Some courts denied on the basis that consular access was not a right pertaining to an individual, or at least not a right of constitutional dimension. Other courts denied on the basis that the issue had been procedurally defaulted by not being raised at an earlier stage, or that a consul's participation would not have provided any real assistance. ${ }^{7}$

In 1998, the Government of Paraguay approached the International Court of Justice (ICJ), seeking to bar Virginia from executing a Paraguayan national, Angel Breard, who faced imminent execution for capital murder. Breard had not been informed about consular access upon arrest. The U.S. Court of Appeals had denied relief on the grounds that Breard did not raise the consular access

3. See Luke T. Lee \& John Quigley, Consular Law and Practice 147 50 (2008); 7 U.S. Department of State, Foreign Affairs Manual §§ 412, 415, 423, 424, 443, 444, 453; John Quigley, William J. Aceves \& S. Adele Shank, The LaW of Consular Access: A Documentary GuIDE 19-21 (2010).

4. See, e.g., Faulder v. Johnson, 81 F.3d 515, 520 (5th Cir. 1996).

5. See, e.g., State v. Issa, 752 N.E.2d 904 (2001).

6. See, e.g., Madej v. Schomig, 223 F.Supp.2d 968, 980 (N.D. Ill. 2002).

7. See Faulder v. Johnson, 81 F.3d at 520; Murphy v. Netherland, 116 F.3d 97, 100 (4th Cir. 1997); State v. Loza, No. CA96-10-214, 1997 WL 634348 (Butler Cty. Ct. App. 1997). 
issue in his initial habeas corpus petition. ${ }^{8}$ The ICJ had jurisdiction, because both Paraguay and the United States were party not only to the VCCR but to an Optional Protocol that allows states party to the VCCR to sue each other for violation of consular obligations. ${ }^{9}$ The ICJ issued an interim (injunctive) order asking the United States to refrain from carrying out the execution. ${ }^{10}$ The U.S. Supreme Court declined to issue a stay of execution, finding that Breard's consular access claim had been procedurally defaulted for not being filed in the time required by the laws of Virginia. ${ }^{11}$ After the Governor of Virginia denied clemency, the execution was carried out. ${ }^{12}$

A few months earlier, the Government of Mexico had initiated action on the consular access issue at the Inter-American Court of Human Rights. Functioning under the Organization of American States (OAS), this Court sits in San Jose, Costa Rica, and has jurisdiction to render advisory opinions on any treaty "concerning the protection of human rights in the American states." ${ }^{13}$ The Government of Mexico sought an opinion about legal remedies required for failure to inform a foreign national about consular access in capital cases. In October 1999, the Court issued an advisory opinion, saying that the VCCR consular access provision, while creating obligations between states, also gives a right to the foreign national. The Court said that the execution of a foreign national who had not been informed of the right of consular access would be unlawful as an arbitrary deprivation of life. ${ }^{14}$

By that date, Germany had filed against the United States in the ICJ, on behalf of a German national who faced imminent execution in Arizona. Like Paraguay, Germany was party to the VCCR and its Optional Protocol. As in the Paraguay case, the ICJ issued an interim order against execution while the case was pending. ${ }^{15}$ Germany sued

8. Breard v. Pruett, 134 F.3d 615, 620 (4th Cir. 1997).

9. Optional Protocol Concerning Compulsory Settlement of Disputes, Apr. 24, 1963, 596 U.N.T.S. 487.

10. See Case Concerning Vienna Convention on Consular Relations (Para. v. U.S.), 1998 I.C.J. 348 (June 9).

11. Breard v. Greene, 523 U.S. 371, 376 (1998).

12. David Stout, Clemency Denied, Paraguayan Is Executed, N.Y. TIMES, Apr. 15, 1998, at A18.

13. American Convention on Human Rights, art. 64(1), Nov. 22, 1969, 1144 U.N.T.S. 123 .

14. Right to Information on Consular Assistance in the Framework of the Guarantees of Due Process of Law, Advisory Opinion OC-16/99, InterAm. Ct. H.R. (ser. A), No. 16, ๆ 7 (Oct. 1, 1999).

15. See LaGrand Case (Ger. v. U.S.), Interim Protection Order, 1999 I.C.J. 9 (Mar. 3). 
in the U.S. Supreme Court, seeking enforcement of the interim order, but the Court found Germany was not in a position to sue. ${ }^{16}$ The German national, Walter LaGrand, was executed, but the ICJ case continued, resulting in a 2001 judgment in which the ICJ said that individual rights are at issue in the obligation to inform about consular access and that a remedy is required. In the case of a conviction of a foreign national who was not informed about consular access, the ICJ said the resulting obligation is "to allow the review and reconsideration of the conviction and sentence by taking account of the violation. . . ."17

Petitions had also been filed in another OAS institution, the Inter-American Commission on Human Rights, on behalf of foreign nationals sentenced to death in the United States but who had not been informed about consular access. The Commission has jurisdiction to hear complaints of rights violations against OAS member states. In two cases of foreign nationals sentenced to death in the United States, these petitions resulted in Commission decisions, one in 2002 and a second in 2003, that the individuals must be afforded a new trial or released from custody. ${ }^{18}$ In each case, the United States informed the Commission that it did not intend to comply.

In 2003 as well, Mexico filed in the ICJ on behalf of fifty Mexican nationals under sentence of death in the United States, the case being styled Avena and Other Mexican Nationals. ${ }^{19}$ Like Paraguay and Germany, Mexico was party to the VCCR and its Optional Protocol. In a 2004 judgment, the ICJ repeated the entitlement to a remedy for individuals who were not informed about consular access, and the ICJ specified-something it had not done in the LaGrand case - that the remedy must be by the judicial branch if such is sought. ${ }^{20}$

In 2006, the issue reached the U.S. Supreme Court again in two cases that the Court combined for argument. In one, a case from Virginia, the foreign national had filed an untimely habeas corpus petition under procedural rules of Virginia. In the other, a case from Oregon, a foreign national sought the suppression of a confession and

16. See Federal Republic of Germany v. United States, 526 U.S. 111, 111-12 (1999).

17. La Grand Case (Ger. v. U.S.), Judgment, 2001 I.C.J. 466, 514 (June 27).

18. Martinez Villareal v. United States, Case 11.753, Inter-Am. Comm'n H.R., Report No. 52/02, OEA/Ser.L/V/II.117, doc. 1 rev. I 86 (2003); Fierro v. United States, Case 11.331, Inter-Am. Comm'n H.R., Report No. 99/03, OEA/Ser./L/V/II.114 Doc. 70 rev. 1 ๆ 72(1) (2003).

19. Avena and Other Mexican Nationals (Mex. v. U.S.), Application Instituting Proceedings, 2003 I.C.J. 128, ๆ 281(1) (Jan. 9).

20. Avena and Other Mexican Nationals (Mex. v. U.S.), 2004 I.C.J. 12, 6566 (Mar. 31). 
had raised the matter in a timely manner. The European Union filed an amicus curiae brief seeking compliance with the ICJ judgments in LaGrand and Avena. ${ }^{21}$ In the Virginia case, the U.S. Supreme Court said that the petition was time-barred (a procedural default). In the Oregon case, the Court said that suppression is not required as a remedy for a violation of the VCCR consular access provision; the Court assumed arguendo that that provision was self-executing but made no ruling on that point, deciding the case instead with respect to remedy. ${ }^{22}$

\section{The President Seeks Implementation of AVena}

Jose Medellín, one of the Mexican nationals named by the Government of Mexico in Avena, filed a habeas corpus petition for relief on the basis of the Avena ICJ judgment. After losing in the lower courts, he went to the U.S. Supreme Court. The European Union filed a brief seeking compliance with the Avena injunction to provide judicial review and reconsideration. The U.S. Solicitor General appeared against Medellín. ${ }^{23}$ While the case was before the Court, however, President George W. Bush sent his Attorney General a memorandum indicating that the United States, recognizing an obligation under the U.N. Charter, should implement Avena by action of the courts of the states in which a particular foreign national was convicted. ${ }^{24}$ U.N. Charter Article 94 requires a state that is party to a case before the ICJ to comply with a judgment that might be rendered..$^{25}$

On the basis of President Bush's memorandum, Medellín filed a new habeas corpus petition in Texas. Medellín's lawyers evidently regarded the president's memorandum as altering the situation in Medellín's favor. Instead of Medellín as an individual making a claim against Texas, now the president was espousing Medellín's cause as that of the federal government. Their decision to file a new habeas corpus action based on the president's memorandum led the U.S.

21. See Brief of Amici Curiae the European Union and Members of the International Community in Support of Petitioners, Sanchez-Llamas v. Oregon, 548 U.S. 331 (2006) (Nos. 04-10566, 05-51).

22. See Sanchez-Llamas v. Oregon, 548 U.S. 331 (2006).

23. Brief for the United States as Amicus Curiae Supporting Respondent, Medellín v. Dretke, 544 U.S. 660 (2005) (No. 04-5928).

24. Memorandum for the Attorney General, Compliance with the Decision of the International Court of Justice in Avena (Feb. 28, 2005), available at http://georgewbush-whitehouse.archives.gov/news/releases/2005/02/ 20050228-18.html. See also Medellín v. Texas, 552 U.S. 491, 523-32 (2008).

25. U.N. Charter art. 9, para. 1. 
Supreme Court, in a five-to-four ruling, to terminate proceedings, to afford the Texas court an opportunity to provide the relief Medellín sought. ${ }^{26}$ Justice O'Connor, along with three of her colleagues, dissented from the dismissal and in her dissent wrote sympathetically about self-execution of the obligation to inform about consular access, and about the need to circumvent state rules on procedural default. ${ }^{27}$

Acting on Medellín's new habeas corpus petition, the Texas Court of Criminal Appeals decided not to comply with President Bush's wish that the relevant state court provide review and reconsideration. The Texas court said that Medellín had procedurally defaulted and that no law outside of Texas could prevail over its procedural law. ${ }^{28}$

The U.S. Supreme Court granted certiorari to Medellín a second time. The European Union filed again, and the U.S. Attorney General did as well. ${ }^{29}$ This second Medellín proceeding in the Supreme Court was unusual. Although it was in form a habeas corpus action initiated by Medellín, the Solicitor General participated and argued that the decision reflected in the president's memorandum, aimed as it was at enforcing a treaty obligation of the United States, was binding on Texas. Thus, the case related as much to the power of the federal government as it did to the rights of Medellín as an individual. The United States, in its brief as amicus curiae, argued that the Texas court was required to provide the review requested by President Bush solely on the basis of the president's obligation and power to comply with UN Charter Article 94..$^{30}$

In a six-to-three ruling, the Court rejected Medellín's petition. ${ }^{31}$ The Court was now in a different composition in this ruling on the second certiorari petition by Medellín. Since the first grant of certiorari, Justice O'Connor had retired and had been replaced by Justice Alito.

To reach that result, the Court sidelined the issue of the president's power. The Court framed the issue in the case to be that of whether the U.N. Charter Article 94 obligation was self-executing; the Court said it was not. Only then did the court address the power of the president and said that, since the Article 94 obligation is not self-executing, the president may not require Texas to comply with it. "[T]he executive," the Court declared, "cannot unilaterally execute a

26. See Medellín v. Dretke, 544 U.S. 660, 661-67 (2005).

27. Id. at 686-90 (O'Connor, J., joined by Stevens, Souter, Breyer, JJ., dissenting).

28. Ex Parte Medellín, 223 S.W.3d 315, 342-43 (Tex. Crim. App. 2006).

29. Brief for the United States as Amicus Curiae Supporting Petitioner, Medellín v. Texas, 552 U.S. 491 (2008) (No. 06-984).

30. See id. at 8-21.

31. See generally Medellín v. Texas, 552 U.S. 491 (2008). 
non-self-executing treaty by giving it domestic effect." ${ }^{32}$ The United States did not regard as relevant whether the Article 94 obligation was or was not self-executing. ${ }^{33}$

\section{A. The Obligation to Review and Reconsider}

The remedy that the Solicitor General and Medellín sought to enforce was a mild one at best. The ICJ in Avena said that when a conviction of a serious offense was gained absent compliance with consular access obligations, the courts must "review and reconsider" in light of the violation:

[T] he legal consequences of this breach have to be examined and taken into account in the course of review and reconsideration. The Court considers that it is the judicial process that is suited to this task. ${ }^{34}$

The ICJ did not require a reversal. It did not indicate how the violation must be "taken into account" in relation to the judicial proceedings before a remedy would be required, or even what that remedy had to be.

The ICJ did not indicate whether the violation must be found to have impacted the proceedings in some specific way. If that were to be required, a reviewing court would have to speculate about what a consul might have done. In the Paraguay case before the ICJ, the United States had asserted, in oral argument on Paraguay's request for an interim order, that one cannot reliably determine after the fact what impact the participation of a consul might have had. The United States said, "[i]t would be unworkable for a court to attempt to determine reliably what a consular officer would have done and whether it would have made a difference." ${ }_{35}$ Some U.S. courts have recognized this difficulty. The Oklahoma Court of Criminal Appeals said in one case that it rejected any approach "which would require a defendant to show that the consular assistance would, or could, have made a difference in the outcome of the criminal trial." 36

Mexico had argued to the ICJ that a violation should lead to reversal, without further inquiry. Invoking the principle well known to international law that the violation of an obligation requires

32. Id. at 530 .

33. Brief for the United States as Amicus Curiae Supporting Petitioner, supra note 29 , at $8-21$.

34. Avena and Other Mexican Nationals (Mex. v. U.S.), 2004 I.C.J. 12, 6566 (Mar. 31).

35. Request for the Indication of Provisional Measures (Para. V. U.S.), 1998 I.C.J. Pleadings 37, ๆ 2.18 (Apr. 7).

36. Torres v. Oklahoma, 120 P.3d 1184, 1187 (Okla. Crim. App. 2005). See generally Quigley, ACEVES \& SHANK, supra note 3, at 150-61. 
restoration of the status quo ante, Mexico said that if a foreign national were convicted and sentenced without having been informed about consular access, the conviction and sentence must be vacated. ${ }^{37}$ The ICJ rejected this automatic approach, saying that "it is for the courts of the United States to examine the facts, and in particular the prejudice and its causes, taking account of the violation of the rights set forth in the Convention." 38

The ICJ, though it had come down on Mexico's side on the issue of an obligation to comply with consular access, tread lightly on the issue of remedy. Said the ICJ, "[i]t is not to be presumed, as Mexico asserts, that partial or total annulment of conviction or sentence provides the necessary and sole remedy." 39 What the ICJ was asking, hence what the president was asking, was a hearing at which the courts of Texas would have some discretion in analyzing the facts.

The Texas Court of Criminal Appeals had in fact already given its view of the impact of the VCCR violation. In ruling on an earlier habeas corpus petition of Medellín's, it said not only that he had procedurally defaulted, but that even if he had not, his VCCR claim would have failed because, according to the court, he had not shown that lack of notification about consular access affected the validity of his conviction or punishment. ${ }^{40}$ So President Bush's memorandum was asking the Texas Court of Criminal Appeals to make a finding of fact it had already made. Nonetheless, the Texas Court of Criminal Appeals instead challenged the president's power to require it to review its earlier decision.

\section{B. President Bush's Mode of Seeking Implementation}

The president treaded lightly in another way, and his decision in this regard ultimately doomed the federal effort at gaining compliance with the treaty obligation. The obligation of the United States qua state rested on two separate but related bases. The United States was obligated to comply with the VCCR consular access provision. On that point, the United States took the view that an individual has no right qua individual, despite the ICJ view to the contrary.

The second basis was the U.S. obligation to comply with a decision of the ICJ in a case to which it was a party. This was the obligation President Bush sought to implement by his memorandum, despite the U.S. disagreement on the merits with the Avena ruling. By virtue of the U.N. Charter, a state that is party to a case, as the

37. Avena and Other Mexican Nationals, 2004 I.C.J. at 58.

38. Id. at 60 .

39. $I d$.

40. Ex parte Medellín, 223 S.W.3d 315, 322 (Tex. Crim. App. 2006) (citing Ex parte Medellín, No. WR-50, 191-01 (Tex. Crim. App. 2001)). 
United States here was, "undertakes" to comply with the Court's judgment, even if it considers the judgment wrong. ${ }^{41}$

But President Bush treaded lightly in seeking implementation of the Avena ruling. He framed the matter as a request, in apparent expectation that the courts of the relevant states would comply, presumably upon request by the foreign nationals whose fate was involved. President Bush did not take direct action against the states in question. The U.S. Attorney General had a basis for suing Texas, either before making a request or after the Texas Court of Criminal Appeals declined, for frustrating the U.S. obligation to carry out a judgment of the ICJ.

In fact, in other situations when another governmental authority's action has put the United States in violation of a treaty obligation, the U.S. federal government has sued. It sued the State of Washington for acts that put the United States in violation of the fishing rights of Native Americans under treaties with tribes. ${ }^{42}$ It has sued municipalities that put the United States in violation of treaty commitments by imposing property tax on diplomatic premises. ${ }^{43}$ In one instance, it sued the Sanitary District of Chicago, which was diverting Lake Michigan waters in violation of a treaty on water levels in the Great Lakes. ${ }^{44}$ Here Texas was placing the United States in violation of its U.N. Charter obligation - an obligation no one contested - to comply with the Avena judgment.

Another of the anomalies was that the LaGrand and Avena cases would not have reached the ICJ in the first place had the U.S. courts provided the remedies required under international law for violation of the obligation to inform a foreign national about consular access. The U.S. courts should have heeded the advisory opinion of the InterAmerican Court of Human Rights, and even without that opinion they should have provided remedies for violations of the obligation to inform about consular access. In 2006, the U.S. Supreme Court had an ideal opportunity to do so but instead ruled, in Sanchez-Llamas v. Oregon, on two issues in a way that would make it difficult for foreign nationals to gain a remedy. It ruled, over and against the norm that a treaty violation must be remedied if at all possible, that a foreign national may not initiate legal action for a remedy for a VCCR violation beyond the time permitted by the procedural law of the particular state. ${ }^{45}$ It ruled further that no remedy, at least the remedy

41. U.N. Charter, art. 94, para. 1.

42. See United States v. Washington, 520 F.2d 676 (9th Cir. 1975).

43. See United States v. Arlington, 669 F.2d 925 (4th Cir. 1982); United States v. Glen Cove, 450 F.2d 884 (2d Cir. 1971).

44. See Sanitary Dist. of Chicago v. United States, 266 U.S. 405 (1925).

45. Sanchez-Llamas v. Oregon, 548 U.S. 331, 357-60 (2006). 
of suppression of a pre-trial statement, is required for a VCCR violation. ${ }^{46}$ In Sanchez-Llamas, the Court assumed arguendo, as it had done in Breard v. Greene, that the VCCR obligation to inform a foreign national about consular access is self-executing, but again, it did not decide that issue.

\section{Self-ExeCUtion in the Supreme Court's AnAlysis}

In any event, as Medellín came back to the U.S. Supreme Court for a second time, Texas argued that the issue was whether U.N. Charter Article 94 was self-executing and said that it was not. ${ }^{47}$ The United States wrote in response as amicus curiae, but its brief read like that of a party. Formally, the United States was not a party, but certiorari had been granted on two questions, the first of which was the power of the president to direct the courts of Texas as he had done. The second was the more general question of whether the ICJ judgment in Avena needed to be implemented judicially.

The United States disputed Texas' proposition that the issue was self-execution. Texas, the U.S. Attorney General wrote, "contends that because the obligation to comply with Avena is not selfexecuting, the President lacks power to implement the decision. That contention lacks merit." 48 The U.S. Attorney General asserted a power for the president to require compliance by Texas with U.N. Charter Article $94 .{ }^{49}$ The U.S. Attorney General regarded the selfexecution doctrine as irrelevant..$^{50}$

The U.S. Supreme Court, however, focused on the second question on which it had granted certiorari. And on that question, it raised self-execution as key to whether the ICJ judgment in Avena needed to be implemented judicially. The Court provided little basis for taking this approach to the case. All the Court said as it launched into a self-execution analysis was that the "Court has long recognized the distinction between treaties that automatically have effect as domestic law, and those that-while they constitute international law commitments - do not by themselves function as binding federal law." ${ }^{51}$ Then the Court cited cases in which a private party sought to rely on a treaty provision, but none in which it was the federal

46. Id. at $348-50$.

47. Brief for Respondent, at 19-20, Medellín v. Texas, 552 U.S. 491 (2008) (No. 06-0984).

48. Brief for the United States as Amicus Curiae Supporting Petitioner, supra note 29 , at 26 .

49. Id. at $10-11,24-25,28$.

50. Id. at $26-29$.

51. Medellín v. Texas, 552 U.S. 491, 504 (2008). 
government seeking to implement a treaty provision. ${ }^{52}$ The Court did not explain that it was taking self-execution into a new realm, namely, situations of implementation by the federal executive.

In support of its view that self-execution was irrelevant, the United States had cited in its brief amicus curiae the Gulf of Maine case. ${ }^{53}$ That case involved a 1984 ICJ determination of a maritime boundary between the United States and Canada off the New England coast. ${ }^{54}$ As with Avena, the ICJ judgment in the Gulf of Maine case was not welcomed by the United States. The Gulf of Maine judgment was seen as a blow to U.S. fishing interests in the New England states. Nonetheless, as with Avena, the president took action to implement the judgment, by taking the appropriate administrative action to fix a maritime line in accordance with the ICJ judgment. ${ }^{55}$ Even though the New England states and the fishing industry were unhappy over the result, they acquiesced, and no legal action was taken in opposition. The point the United States was making by citing the Gulf of Maine was that when the treaty obligation to comply with an ICJ judgment fails to be implemented, the president can take appropriate action to that end.

Domestic measures taken by a president to implement a treaty obligation had never been subjected to a self-execution analysis with regard to the particular treaty provision. In the cases cited above in which the federal government had to sue to secure compliance by state-level authorities with a treaty obligation, no party raised selfexecution as an issue. ${ }^{56}$ The self-execution doctrine was elaborated as private parties sought rights based on a treaty. ${ }^{57}$

That aspect of the self-execution doctrine was explained by the Supreme Court in Edye v. Robertson (Head Money cases). ${ }^{58}$ There, the Court first said - and this is language the Court in Medellin quotes - that a treaty is in the first instance a set of obligations running between the states parties, and in case of breach they look to

52. See id. at 504-05.

53. Brief for the United States as Amicus Curiae Supporting Petitioner, supra note 29 , at 20 .

54. Case Concerning Delimitation of the Maritime Boundary in the Gulf of Maine Area (Can. V. U.S.), 1984 I.C.J. 246 (Oct. 12).

55. Brief for the United States as Amicus Curiae Supporting Petitioner, supra note 29 , at 20 .

56. See Sanitary Dist. of Chicago v. United States, 266 U.S. 405 (1925); United States v. Winans, 198 U.S. 371 (1905); United States v. Washington, 520 F.2d 676 (9th Cir. 1975).

57. See Foster v. Neilson, 27 U.S. 253 (1829), overruled on other grounds by United States v. Percheman, 32 U.S. (7 Pet.) 51 (1833).

58. Edye v. Robertson (Head Money Cases), 112 U.S. 580 (1884). 
each other for satisfaction. ${ }^{59}$ But the Court in Edye immediately followed that statement with an explanation of how treaty provisions may create rights for individuals:

But a treaty may also contain provisions which confer certain rights upon the citizens or subjects of one of the nations residing in the territorial limits of the other, which partake of the nature of municipal law, and which are capable of enforcement as between private parties in the courts of the country. An illustration of this character is found in treaties, which regulate the mutual rights of citizens and subjects of the contracting nations in regard to rights of property by descent or inheritance, when the individuals concerned are aliens. The constitution of the United States places such provisions as these in the same category as other laws of congress by its declaration that "this constitution and the laws made in pursuance thereof, and all treaties made or which shall be made under authority of the United States, shall be the supreme law of the land." A treaty, then, is a law of the land as an act of congress is, whenever its provisions prescribe a rule by which the rights of the private citizen or subject may be determined. And when such rights are of a nature to be enforced in a court of justice, that court resorts to the treaty for a rule of decision for the case before it as it would to a statute. ${ }^{60}$

In Medellin, the Supreme Court gave a definition of self-executing:

What we mean by "self-executing" is that the treaty has automatic domestic effect as federal law upon ratification. Conversely, a "non-self-executing" treaty does not by itself give rise to domestically enforceable federal law. Whether such a treaty has domestic effect depends on implementing legislation passed by Congress. ${ }^{61}$

The definition in Medellin differs from the definition in the Head Money cases in significant respects. First, the definition in Medellin refers to the treaty as a whole rather than to a specific provision. In this respect the definition in Medellin is at odds with the notion of self-execution as the doctrine was developed by the Supreme Court in the nineteenth century. In Percheman, for example, the treaty in question provided for the transfer of Florida from Spain to the United States, and for various consequences of that transfer. One consequence related to the issue of rights in real property in Florida, and what

59. Medellín v. Texas, 552 U.S. 491, 505 (quoting Edye v. Robertson, 112 U.S. 580, 598 (1884)).

60. Head Money Cases, 112 U.S. at 598-99.

61. Medellín, 552 U.S. at 505 n.2. 
would become of those rights upon the transfer. In Percheman, it was this provision-Article 8 of the treaty - that was relevant. No other provision was relevant. Justice Marshall asked himself whether the provision on real property rights in Article 8 was such that courts should implement it. Had Spain refused to turn Florida over to the United States - a matter dealt with elsewhere in the treaty - the considerations on judicial implementation would have been quite different. Today's Supreme Court would likely agree with the proposition that it is a question of a particular provision. Indeed, the Court approvingly cites Percheman. ${ }^{62}$

But the Medellin court's definition casts doubt on whether a treaty - or more precisely, a treaty provision - has any domestic effect. Contrary to the Head Money definition, the Medellin definition does not focus on the potential rights of a private party. If a treaty has no "domestic effect," it becomes questionable whether the president could implement it over and against a state of the union. The Court in Medellin went into no detail on the point, so one cannot be sure what to conclude from its definition of self-executing. But if taken seriously, the new definition might require that a treaty provision be self-executing before the federal government could sue a state to require implementation.

The doctrine of self-execution is one that comes into play when, and only when, a treaty provision is relied upon by an individual. The doctrine determines whether the individual may rely on the treaty provision. But the doctrine has no relevance when the federal government relies on a treaty provision against a state of the union, or a sub-entity of a state of the union. Such is apparent from the early cases, like Ware v. Hylton, in which private parties relied on a treaty provision, and, indeed, on every self-execution case that has arisen in the courts. ${ }^{63}$

The Constitution, of course, requires the states to comply with treaties. Treaties are declared to be "the supreme Law of the Land; and the Judges in every State shall be bound thereby, any Thing in the Constitution or Laws of any State to the Contrary notwithstanding." ${ }_{64}$ That language sounds as if it were written with the Medellin case in mind. The Texas rules on procedural default fall by the wayside in the face of a treaty obligation. The Supreme Court has had little difficulty in finding treaty provisions to prevail over state law. In one early case, the rights of a British creditor under the

62. See id. at 514 .

63. See Ware v. Hylton, 3 U.S. (3 Dall.) 199 (1796).

64. U.S. Const. art. VI, cl. 2. See also Carlos Manuel Vázquez, TreatyBased Rights and Remedies of Individuals, 92 Colum. L. Rev. 1082, 1101-08 (1992); Tim Wu, Treaties' Domains, 93 VA. L. Rev. 571, 60203 (2007). 
debt restoration provisions of the Treaty of Paris ran counter to a statute of limitations provision in Virginia law on the relevant financial obligation. The Supreme Court said that that Virginia law fell in the face of the treaty obligation to restore the debt. ${ }^{65}$ The dissenters in Medellin recited twelve prior cases of the Court in which a treaty provision overrode state law. ${ }^{66}$ Others could be added to their list. ${ }^{67}$ The dissenters, though they argued strongly that UN Charter Article 94 was self-executing, did not pick up on the Attorney General's valid point that self-execution should not have been an issue at all.

\section{The Supreme Court's ReAding of UN Charter ARTICLE 94}

The Court could have minimized the damage of saying that selfexecution was relevant by a proper analysis of U.N. Charter Article 94. But it found Article 94 to be non-self-executing, and to reach that result it engaged in reasoning that is hardly convincing. The Court took Article 94 as a promise of future action, rather than an obligation to be implemented by the courts, because, it said, the term "undertakes" implies a need for future action. ${ }^{68}$ A U.N. member state, per Article 94, "undertakes to comply with the decision of the International Court of Justice in any case to which it is a party." 69 The Court distinguished "undertakes" from "shall" or "must." Use of one of these latter terms, it said, might have bespoken an intent "to vest ICJ decisions with immediate legal effect in domestic courts." 70 The dissenters found the Court's distinction between "undertakes" on the one hand and "shall" or "must" on the other strained. ${ }^{71}$ The dissenters had the better side on this point. "Undertake" as a verb, or "undertaking" as a noun, is used internationally to mean a firm obligation. ${ }^{72}$

65. See, e.g., Hopkirk v. Bell, 7 U.S. (3 Cranch) 454, 457-58 (1806).

66. Medellín, 552 U.S. at 545 (Breyer, J., dissenting).

67. Wu, supra note 64, at 584 n.31 (listing Supreme Court cases in which a treaty provision overrode a state statute or policy).

68. Medellín, 552 U.S. at 508.

69. U.N. Charter art. 94, para. 1.

70. Medellín, 552 U.S. at 508.

71. See id. at 553 (Breyer, J., dissenting).

72. See Carlos Manuel Vázquez, Less Than Zero?, 102 Am. J. InT'L L. 563, 571 (2008); Carlos Manuel Vázquez, Treaties as Law of the Land: The Supremacy Clause and the Judicial Enforcement of Treaties, 122 HARV. L. REV. 599, 661 (2008). 


\section{A. Enforcement Mechanism in UN Charter Article 94}

In a second point the Court took to show the non-self-execution of Article 94, it references a mechanism provided by the second paragraph of Article 94 for enforcement of ICJ judgments. Article 94(2) states:

If any party to a case fails to perform the obligations incumbent upon it under a judgment rendered by the Court, the other party may have recourse to the Security Council, which may, if it deems necessary, make recommendations or decide upon measures to be taken to give effect to the judgment. ${ }^{73}$

Citing this provision, the Court said, "The U.N. Charter's provision of an express diplomatic - that is, nonjudicial-remedy is itself evidence that ICJ judgments were not meant to be enforceable in domestic courts." ${ }^{74}$ The Court did not explain why the existence of a nonjudicial remedy is relevant to self-execution. The Court merely cited its own decision in Sanchez-Llamas for this proposition. ${ }^{75}$ In Sanchez-Llamas, however, neither at the page cited or elsewhere, does one find mention of any alternative remedy that might negate domestic application of the treaty provision there in question. ${ }^{76}$ The Court here confused remedy with self-execution. Sanchez-Llamas was decided on the issue of the availability of a remedy under a treaty provision, not on the issue of self-execution.

In any event, the U.N. Security Council enforcement provision has no relevance to whether U.N. Charter Article 94 is or is not selfexecuting. ${ }^{77}$ The possibility of Security Council enforcement arises only if a party does not comply. It has nothing to do with the issue of how a party complies. The Court, moreover, mischaracterized the Security Council enforcement provision as "the sole remedy for compliance," as if that excludes compliance through a proceeding in a domestic court. ${ }^{78}$ Security Council enforcement is the "sole" remedy at the United Nations, but not necessarily the sole remedy overall.

The Court did not refer to prior self-execution situations and whether the treaty provisions involved did or did not have some enforcement mechanism. U.S. courts routinely allow invocation of

73. U.N. Charter art. 94, para. 2.

74. Medellín, 552 U.S. at 509.

75. $\quad I d$.

76. See Sanchez-Llamas v. Oregon, 548 U.S. 331, 347 (2006).

77. Vázquez, Treaties as Law of the Land, supra note 72 , at 627, n.132 ("The existence of an international enforcement mechanism does not suggest the unavailability of domestic enforcement.").

78. Medellin, 552 U.S. at 509. 
treaty provisions from treaties that provide an enforcement mechanism. The most typical - a remedy found in a number of treaties - is a dispute settlement process, often involving the ICJ. The 1953 Treaty of Friendship, Commerce, and Navigation (FCN) with Japan, for example, contains a clause allowing either party to refer a dispute to the ICJ. ${ }^{79}$ Yet Japanese litigants have successfully invoked provisions of the Treaty as a basis for a right in courts of the United States. In these cases, no issue has been raised that the provision could not be invoked because of the possibility that Japan might sue the United States in the event of breach. ${ }^{80}$ The existence of an enforcement mechanism in a treaty is irrelevant to the question of the self-executing character of particular provisions. Were the Supreme Court to take this position, it would require overturning established case law affecting, in particular, treaties of friendship, commerce, and navigation, like that with Japan. The ability of U.S. corporations to operate effectively in the territory of states with which the United States has such treaties would be jeopardized.

Texas argued in its brief that the enforcement mechanism precluded self-execution of Article $94 .{ }^{81}$ The United States, in its brief as amicus curiae, responded that Texas:

[E]rrs in contending that the provision in the U.N. Charter that permits a party to the agreement to seek enforcement of an ICJ decision in the Security Council shows that the obligation to comply with an ICJ decision may be enforced only diplomatically or politically, and not through domestic courts. That U.N. Charter provision simply recognizes that the political branches of a Nation may choose not to comply with an ICJ decision, and provides that, in that event, recourse to the Security Council is the sole remedy. It does not address the situation where, as here, the President decides to comply with an ICJ decision and exercises authority under treaties to make the decision judicially enforceable. ${ }^{82}$

The U.S. view was more plausible than that of Texas or of the Court. Resort to the Security Council enters the picture only in the event of non-compliance with an ICJ judgment. Three noted commentators on the U.N. Charter have written that "Article 94(2) merely assures the aggrieved party of recourse to the Security Council

79. Treaty of Friendship, Commerce and Navigation (U.S.-Japan), art. 24(2), Apr. 2, 1953, 4 U.S.T. 2063.

80. Papaila v. Uniden Am. Corp., 51 F.3d 54, 55 (5th Cir. 1995); Fortino v. Quasar Co., 950 F.2d 389, 393 (7th Cir. 1991).

81. Brief of Respondent, supra note 47 , at 20.

82. Brief for the United States as Amicus Curiae Supporting Petitioner, supra note 29 , at 27 (internal citations omitted). 
in the event the other party fails to perform its obligations under a judgment of the Court." 83

In an attempt to bolster its point about an alternative enforcement mechanism, the Court pointed out that the Security Council would enjoy some discretion in whether or not to take action, and that the United States holds veto power in the Security Council and therefore could always prevent action against it for noncompliance with an ICJ judgment. ${ }^{84}$ The Court reasoned that since the United States knew it could avoid U.N. Security Council sanctions by exercise of the veto, it must not have contemplated implementation by domestic courts, since a decision by a domestic court to implement an ICJ decision would deprive the United States of its option to avoid the ICJ decision by vetoing a Security Council resolution against the United States. ${ }^{85}$

The exercise of a veto to defeat a Security Council resolution against the United States for not complying with an ICJ decision, at least if there were no excuse for the non-compliance, would be a violation of its obligations under the Charter to act in good faith in fulfilling their Charter obligations ${ }^{86}$ But that point aside, it is not established that the United States ratified the UN Charter with the unspoken understanding the Court ascribed to it. The Court cited statements of administration figures at the Senate hearings preceding ratification to try to establish that such was the understanding. ${ }^{87}$ But those statements merely recite that resort to the Security Council would be a possibility in the event that the United States or any other state were to decline to comply with an ICJ decision. ${ }^{88}$ The cited administration statements suggest nothing about the character of the Article 94 obligation to comply with an ICJ decision as being self-executing or not.

The Court said that if Article 94 were self-executing, "[n]oncompliance with an ICJ judgment through exercise of the Security Council veto .. . would no longer be a viable alternative. There would be nothing to veto." ${ }^{89}$ Therefore, the United States must have considered Article 94 to be non-self-executing. But apart from the absence of historical evidence, there is little logic in the Court's

83. Leland M. Goodrich, Edvard Isak Hambro \& Anne Patricia Simons, Charter of the United Nations: Commentary and DoCuments 556 (1969).

84. Medellín v. Texas, 552 U.S. 491, 509-10 (2008).

85. Id. at 510 .

86. U.N. Charter art. 2, para. 2.

87. Medellín, 552 U.S. at 510.

88. Id.

89. Id. at 510-11. 
reasoning. If a court were to implement an ICJ decision, that would deprive the executive of the option to decline to comply. But to say that the United States entered into a treaty obligation with a strategy for non-compliance would cast serious doubt on the good faith of the United States in becoming party to the UN Charter.

\section{B. ICJ Statute Articles 34(1) and Article 59}

The Court relied on two other provisions of the treaty establishing the ICJ, its statute, to show non-self-execution of Article 94. It referred to Article 34(1), which allows only states to be party to a case, and Article 59, which provides that an ICJ decision "has no binding force except between the parties and in respect of that particular case." 90 The Court cited these two articles as "further evidence that the ICJ's judgment in Avena does not automatically constitute federal law judicially enforceable in United States courts." 11

The Court said that these two articles mean that an ICJ decision could not be used in a U.S. court by José Medellín, because he was not, and could not have been, a party to the ICJ case. ${ }^{92}$ The Court did not explain why it is relevant that José Medellín, as a natural person, could not, under Article 34(1), be a party to an ICJ case, in particular to the Avena case. The Avena case, though brought by a state, Mexico, was instituted to protect rights of its nationals, including Medellín. The dissenters correctly pointed out that the Article 94 obligation to comply may require a party to ICJ litigation to afford a right that attaches to a national of the adverse party. ${ }^{93}$

ICJ Statute Article 59, on which the Court also relied, likewise provides little support for its conclusions. Article 59 says an ICJ decision has binding force only between the parties, reflecting a concern that ICJ decisions would not be taken as precedent in future cases in the ICJ itself. ${ }^{94}$ Article 59 has no relevance to domestic implementation..$^{95}$

90. Statute of the International Court of Justice, art. 59(1), June 26, 1945, 59 Stat. 1055, 33 U.N.T.S. 993.

91. Medellin, 552 U.S. at 511.

92. Id. at 512 .

93. Id. at 558-59 (Breyer, J., dissenting).

94. See 2 The Charter of the United Nations: A Commentary 1175 (Bruno Simma ed., 2002) (describing how if the ICJ grants permission for intervention, the intervening state does not become a party to the dispute, and consequently, is not bound by the judgment).

95. Vázquez, Treaties as Law of the Land, supra note 72, at 647 (stating that the Court's reliance on Article 59 has "little to do with any version of the self-execution question"). 
CaseWestern Reserve Journal of International LaW · Vol. $45 \cdot 2012$ A Tragi-Comedy of Errors Erodes Self-Execution of Treaties

\section{Conflict With Prior Self-Execution Decisions}

Going beyond its self-execution analysis of U.N. Charter 94, the Court generalized about standards for self-execution:

Given that ICJ judgments may interfere with state procedural rules, one would expect the ratifying parties to the relevant treaties to have clearly stated their intent to give those judgments domestic effect, if they had so intended. Here there is no statement in the Optional Protocol, the U.N. Charter, or the ICJ Statute that supports the notion that ICJ judgments displace state procedural rules. ${ }^{96}$

The Court thus conceded that a treaty may override a state procedural rule, but its reference to the need for a "statement" about domestic effect appeared to require more than the Court had required in prior cases. The dissenters objected to what appeared to be a requirement of a more or less explicit indication in the treaty itself that a provision was to be implemented by the judicial branch of government. ${ }^{97}$

What the Court intended was far from clear. It approvingly cited Percheman as an instance of a treaty provision that was selfexecuting. ${ }^{98}$ The Court in Medellin said that the reason for the result in Percheman was that the language indicated the parties' intent to confirm the land grant "by force of the instrument itself." ${ }^{99}$ But the treaty provision at issue in Percheman contained no "statement" that it was to have domestic effect. The Supreme Court in Percheman inferred an intent for judicial implementation on the basis of a clause guaranteeing the continuation of property titles upon a change in sovereignty in Florida from Spain to the United States. The clause read: "[T]he grants shall remain ratified and confirmed to the persons in possession of them." ${ }^{100}$ Nothing was said in the treaty as to how this obligation should be implemented in the domestic law of the United States. ${ }^{101}$ There was nothing more in the treaty with Spain than in the U.N. Charter on the domestic law implications.

96. Medellín, 552 U.S. at 517.

97. Id. at 549 (Breyer, J., dissenting).

98. See $i d$. at 514 .

99. Id. at 514 (citing United States v. Percheman, 32 U.S. (7 Pet.) 51, 89 (1833)).

100. Treaty of Amity, Settlement, and Limits Between the United States of America and His Catholic Majesty (Spain-U.S.), art. 8, Feb. 22, 1819, 8 Stat. 252.

101. United States v. Percheman, 32 U.S. (7 Pet.) 51, 88 (1833). 
The Court, in fact, has repeatedly found treaty provisions to be self-executing when there was no "statement" in the text of the treaty. ${ }^{102}$ Indeed, such "statements" would be hard to find in any of the treaties whose provisions the Court has found to be self-executing. The treaty provision at issue in United States v. Rauscher read simply as a set of obligations between Britain and the United States to effectuate extradition for certain named criminal offenses. ${ }^{103}$ The treaty contained no "statement" about how the obligations were to be put into effect in domestic law. ${ }^{104}$ In Britain, of course, treaty provisions never have domestic effect absent parliamentary incorporation, so such a statement would have been unacceptable to Britain. ${ }^{105}$ Rauscher was extradited to the United States under the treaty for one particular crime - murder. Once Rauscher was in the United States, the prosecuting attorney filed an additional charge on one other crime. The U.S. Supreme Court said Rauscher could invoke the treaty provision and that the provision prohibited the normal exercise of discretion of the prosecutor, because under the unwritten law of extradition, a person extradited on one offense may not be charged with another. ${ }^{106}$ The treaty itself contained no "statement" that the extradition provision might accord any rights to a person being extradited or that it might displace procedural rules. ${ }^{107}$ Yet the Supreme Court found the treaty provision to afford a right to the person surrendered that an additional charge not be filed.

The treaty provision at issue in Asakura $v$. City of Seattle simply gave nationals of the United States and Japan the right to carry out business in the other's territory on a par with locals. ${ }^{108}$ There was no "statement" in the treaty that related to domestic enforcement. Yet in Asakura and other cases, the Supreme Court has found a treaty provision to be self-executing absent any "statement" that "supports" domestic enforcement or the displacement of rules of domestic law.

102. Medellín, 552 U.S. at 547 (Breyer, J., dissenting).

103. United States v. Rauscher, 119 U.S. 407, 410-11 (1886).

104. Webster-Ashburton Treaty, U.S.-Britain, art. 10, Nov. 10, 1842, 8 Stat. 576 .

105. See generally International Humanitarian Law: National Implementation, INT'L COMM. OF THE RED CROSS, available at http://www.icrc.org/ihl-nat.nsf/f80f8f25c8ba70cd41256486004ad095 /e259f85e9400552cc1256ba700532b80!OpenDocument (stating that "it is frequently the case that the enactment of domestic legislation by Parliament is a prerequisite for ratification of a treaty by the government").

106. Rauscher, 119 U.S. at 410-11.

107. Id.

108. Asakura v. City of Seattle, 265 U.S. 332, 340 (1924). 
Yet the Supreme Court has had no difficulty concluding that such treaty provisions were self-executing. ${ }^{109}$

In Sanchez-Llamas, as noted, the Court said before it can provide a remedy for a treaty violation in a way that would apply in a state court, the authority for a judicial remedy "must lie, if anywhere, in the treaty itself." 110 Putting that proposition together with the requirement for explicitness for domestic enforcement per Medellín, the chances for a treaty-based remedy in a domestic court of the United States may seem remote. It is unclear just what the Court will require in future cases. The Court's statement in Sanchez-Llamas about remedy is just as out of keeping with its own case law as the statement in Medellin about domestic enforcement. In none of the cases related above-Hopkirk, Rauscher, Asakura - was there any mention of remedy in the treaty itself. Yet the Court provided a remedy. As Lori Damrosch rightly said, "the Court has typically afforded judicial remedies for treaty violations, regardless of whether the treaty itself specified the availability of such remedies." 111

Medellin and Sanchez-Llamas thus go at domestic enforcement from two perspectives: Medellin from the perspective of domestic application and Sanchez-Llamas from the perspective of remedy. With respect to each, the Supreme Court is now seriously at odds with its own prior cases, a fact that it does not acknowledge. It may be that the Court in future will limit these extreme interpretations to certain kinds of cases only. It is, to be sure, a greater acceptance of a treaty obligation when that obligation requires compliance with the decisions of an international court to be made in the future, whether or not the reasoning of the international court passes muster. The Court in Medellin referred to this circumstance. ${ }^{112}$ The frailty of the analysis in Medellin and Sanchez-Llamas may incline the Court in future to find limitations or simply to ignore these cases.

When the Supremacy Clause was written, treaty provisions related to a small range of issues. The proliferation of human rights treaties from the mid-twentieth century has placed a strain on the Supremacy Clause. The Court has confronted a similar problem in implementation of the Alien Tort Claims Act, which, when adopted in 1789, applied to a narrow range of internationally defined torts. Now the Act potentially encompasses a huge number. The Supreme Court has shown itself reluctant to apply the Act to a broad range. ${ }^{113}$

109. See id. at 341 .

110. Sanchez-Llamas v. Oregon, 548 U.S. 331, 346 (2006).

111. Lori F. Damrosch, Medellín and Sanchez-Llamas: Treaties from John Jay to John Roberts, in InTERnATIONAL LAW IN THE U.S. SUPREME Court: Continuity And Change 460 (David L. Sloss et al. ed., 2011).

112. Medellín v. Texas, 552 U.S. 491, 518 (2008).

113. See Sosa v. Alvarez-Machain, 542 U.S. 692, 724-25 (2004). 
The Court said that the courts of other states of the world would not apply a comparable ICJ decision against that state as domestic law. There is little domestic litigation one way or the other in the courts of the world. Yet in the predecessor case, Medellin v. Dretke, forty-six European governments and thirteen from Latin America filed amicus curiae briefs in which they declared their courts would provide a remedy in line with the Avena prescription, should the issue arise.

\section{Meaning of MedelLÍN For Defensive Invocation OF A TREATY}

The Supreme Court explained in a footnote in Medellin what it meant by "self-executing" and "non-self-executing":

The label "self-executing" has on occasion been used to convey different meanings. What we mean by "self-executing" is that the treaty has automatic domestic effect as federal law upon ratification. Conversely, a "non-self-executing" treaty does not by itself give rise to domestically enforceable federal law. Whether such a treaty has domestic effect depends upon implementing legislation passed by Congress. ${ }^{114}$

The American Bar Association-American Society of International Law (ABA-ASIL) Joint Task Force on Treaties in U.S. Law took this note to negate defensive invocation of a treaty provision if the provision is deemed to be non-self-executing and to negate invocation offensively under a statute that provides a cause of action such as 42 U.S.C. $\S 1983$ or 28 U.S.C. $\S 1331 .{ }^{115}$ The Task Force was set up in response to the Medellin decision. The Court's definition of selfexecuting as applied to these two possible modes of invocation must be regarded as dictum since neither was at issue in Medellín.

As for defensive invocation, the position stated in the Court's note would put the Court at odds with the Senate Foreign Relations Committee, which has explained that "non-self-executing" means only that the relevant treaty provisions "will not create a private cause of action in U.S. courts." 116 The Committee definition would not preclude defensive invocation, which is the way in which treaty provisions are typically invoked in the criminal law context, and often under FCN and other treaties. In a number of FCN treaty cases, Japanese firms that hired Japanese nationals for executive positions and were sued for discrimination invoked an FCN treaty provision

114. Medellin, 552 U.S. at 505 n.2.

115. Am. Bar Assoc. \& Am. Soc'y Int'l L., Joint Task Force on Treaties in U.S. Law 9 (Working Paper, Mar. 16, 2009), available at http:// www.asil.org/files/TreatiesTaskForceReport.pdf.

116. S. REP. No. 102-23, at 19 (1992), reprinted in 31 I.L.M. 645, 657. 
defensively to counter the allegation of discrimination. FCN treaty provisions according rights are likely to be found self-executing, so defensive invocation is likely to succeed in future cases.

As for 42 U.S.C. $\S 1983$ suits relying on treaty provisions, some lower courts have allowed such use on the rationale that $\S 1983$ provides the cause of action. ${ }^{117}$ Were the Supreme Court to insist on such a broad view of non-self-execution, it would put the Court at odds with these lower court decisions. It would also put the Court in conflict with the Senate Foreign Relations Committee's understanding of non-self-execution. ${ }^{118}$ The Senate has frequently appended a declaration of non-self-execution to its resolutions giving consent to the ratification of human rights treaties. The Senate Foreign Relations Committee, as noted, means by self-execution only that no private cause of action is created.

\section{MeAning of MEDELlin For ExeCutive ENFORCEMENT OF A TREATY}

The ABA-ASIL Task Force raises the prospect that the Court's view of self-execution in Medellin might even prevent the president from acting to comply with treaty obligations. ${ }^{119}$ This concern arises from the Court's definition, recited above, of self-execution. ${ }^{120}$ The Task Force considers the example of environmental or maritime-safety treaties that create a mechanism for future standard-setting. Standards set in this fashion are typically implemented for the United States by the president. ${ }^{121}$ Such concern would seem groundless, however, because the self-execution doctrine as it has been elaborated by the Supreme Court relates to judicial enforcement alone. The issue arises under the Supremacy Clause, which concerns the courts, not the executive branch.

The issue could arise if the president seeks to implement a treatybased obligation through the courts. Per Medellin, the president might face a problem if the particular treaty provision is asserted to be non-self-executing. The President would need to argue either that the treaty provision is in fact self-executing, or that the doctrine of self-execution does not apply when it is the President, rather than a

117. See, e.g., Standt v. City of New York, 153 F. Supp. 2 d 417 (S.D.N.Y. 2001).

118. See, e.g., International Covenant on Civil and Political Rights, Declarations \& Reservations, United States of America, Dec. 16, 1966, 999 U.N.T.S. 171("[T]he United States declares that the provisions of articles 1 through 27 of the Covenant are not self-executing.").

119. Am. Bar Assoc. \& Am. Soc'y Int'l L., supra note 115, at 12.

120. See id.

121. Id. at 11 . 
private party, seeking implementation. The Court in Medellin did not squarely face the latter question because the moving party was Medellín. The precedents cited above uniformly omit any need for self-execution when it is the federal government suing a governmental entity to require that entity to act in a way that will keep the United States in compliance with a treaty obligation. ${ }^{122}$

The president could, for example, even without relying on the U.N. Charter Article 94 obligation to comply with an ICJ decision, sue the state of Texas, in relation to any of the other foreign nationals on death row there who were not informed about consular access, for failing to implement that VCCR obligation. The federal executive would, to be sure, have to alter its own view of what is required as a remedy for a consular access violation. If the Supreme Court were to say that self-execution is required even when the president sues, the president would have to argue that the obligation to inform about consular access is self-executing, an issue that the Supreme Court, as noted, left open in the Sanchez-Llamas case. Properly, of course, selfexecution is irrelevant when the president sues.

In one context in which the executive branch has sued to implement a treaty obligation, namely, the imposition of property tax by a local government on premises entitled to diplomatic immunity, it would seem absurd to raise the question of whether that treaty obligation is self-executing. In that situation, unlike that in Medellin, no individual is involved at all. It is simply a question of U.S. implementation of the rights of a foreign state under an obligation based either on a treaty or on customary law not to require the payment of property tax. In the lower court cases decided to date on that issue, self-execution was never mentioned as being necessary for the federal government to gain a judgment against the local governmental entity. ${ }^{123}$ Self-execution comes into play, at least in the cases decided by the Supreme Court to date, only when it is a private party seeking implementation.

\section{ViII. Declaration in a Senate Resolution of CONSEnT}

The Senate Foreign Relations Committee reacted to Medellin by deciding that it should include a declaration in each treaty it proposes to the Senate for advice and consent that the treaty either is or is not self-executing. ${ }^{124}$ There is some imprecision in such an approach, because it is unlikely that each and every provision of any treaty will

122. See supra notes 42 to 44 and accompanying text.

123. See United States v. Arlington, 669 F.2d 925 (4th Cir. 1982); United States v. City of Glen Cove, 450 F.2d 884 (2d Cir. 1971).

124. See S. ExEc. Doc. No. 110-12, § VIII(B) (2008). 
be self-executing. The Senate, for example, proposed such a declaration to be included in the advice and consent resolution for the 2003 Extradition Treaty Between the European Union and the United States of America. While most of the Treaty's provisions are to be applied by the courts as they consider an extradition request, some create strictly government-to-government obligations, such as an article providing for review of the treaty after five years. ${ }^{125}$ The Senate gave consent to the Extradition Treaty subject to the declaration, which read, "[t]his Treaty is self-executing." 126

There is some danger in the Committee's approach. If it becomes practice to include such a declaration, then if in a particular treaty no such declaration is included, the courts might draw a negative inference. Moreover, what the Court seemed to require was a statement in the treaty itself. It is unclear whether the Court would consider sufficient a declaration that is not contained in the treaty's text.

\section{The Supreme Court's Operational Rule}

David Sloss has persuasively argued that the courts apply the Supremacy Clause differently depending on the identity of the defendant. ${ }^{127}$ If a private party claims a treaty-based right against another private party, the courts incline to find the treaty provision self-executing and to consider that a remedy is required. If a private party claims a treaty-based right against a governmental entity, the courts incline to find the treaty provision non-self-executing and to consider that no remedy is required. That result is particularly pronounced if the private party is being prosecuted for crime and seeks to rely on the treaty-based right to oppose the prosecution. ${ }^{128}$ Nothing on the face of the Supremacy Clause justifies this differential approach. But asserting a treaty-based right against a governmental entity seems to evoke concern in the judiciary that the United States is being ruled from outside, whereas when the rights of two private parties are at issue, the matter is viewed simply as one in which the government has, by treaty, provided for a particular result.

This distinction, based in realpolitik more than legal principle, may well account for the unfortunate analysis seen in Medellín. A

125. Extradition Treaty Between the European Union and the United States of America, art. 21, June 25, 2003, T.I.A.S. No. 10-201.

126. 154 CONG. REC. 20167 (Sept. 23, 2008).

127. See generally David Sloss, United States, in The Role of Domestic Courts in Treaty Enforcement: A Comparative Study 504 (David Sloss ed., 2009) (analyzing the impact of the Supremacy Clause on a "database of cases").

128. See id. 
foreign entity, the ICJ, was telling the United States it had to provide Medellín a right, albeit a right that likely would not have benefited Medellín in the long run, in contravention of the procedural law of a state of the union.

Treaty-based rights running against the government have been enforced by the courts. In Rauscher, the relief sought based on a treaty ran against a governmental entity. The U.S. Supreme Court told a federal prosecutor to drop a criminal charge. ${ }^{129}$ With the proliferation of human rights treaties in the late twentieth century, however, the potential for interfering with governmental action affecting individuals increased exponentially. The courts began to look more carefully at rights-creating provisions of treaties when the right ran against the government. ${ }^{130}$ The Senate reacted in the approval process for treaties by inserting in rights-giving treaties a declaration, albeit a declaration of unclear meaning and effect, that rights provisions were to be deemed non-self-executing.

Such rights, of course, are rights that the United States has agreed, by virtue of adhering to a particular treaty, to implement. So the attitude that something is being imposed from outside is not based on a logical analysis. If the United States regards it as beneficial, whether to secure better protection for U.S. nationals at the hands of other states of the world, or for any other reason, to enter into a treaty that provides for rights, then it is the United States that is making the decision that a particular right needs to be respected.

To be sure, that decision is being made at the federal level. What comes through in Medellin and Sanchez-Llamas opinions is a concern on the part of the Supreme Court that the federal government is overriding the rights of the states. What the judges are ignoring is that entry into a treaty requires the approval of two-thirds of the U.S. Senate (of members present and voting) and that the Senate was set up under the Constitution to provide representation for states. The advice and consent process allows the states to keep the federal government from entering into treaties that may have effects adverse to the interests of the states. If the states, as represented in the Senate, do not want the federal executive to enter into a particular treaty, they can readily prevent it.

The Supreme Court in Medellin poses, as if it were an unacceptable outcome, the prospect that the ICJ might make a bad decision. ${ }^{131}$ Would it need to be implemented by the United States?

129. See United States v. Rauscher, 119 U.S. 407, 430 (1886).

130. See Oona A. Hathaway, Sabria McElroy \& Sara Aronchick Solow, International Law at Home: Enforcing Treaties in U.S. Courts, 37 YALE J. INT'L L. 51, 63-65 (2012).

131. Medellín v. Texas, 552 U.S. 491, 517-18. 
The answer is yes. In the law one often finds rules that lead to a result that is less than pleasant. A criminal suspect who committed an outrageous crime and who admitted to it may be able to suppress that statement because the constable blundered by not advising about constitutional rights. Yet we live with such results, on the rationale that the rule is necessary.

\section{Treaties in Private Law Cases Post-Medellín}

In a 2012 article, Oona A. Hathaway, Sabria McElroy, and Sara Aronchick Solow claim that the lower courts have taken the more stringent requirement suggested in Medellin beyond the context of rights sought against governmental entities and are applying it across the board to all treaty-based claims, including suits against private parties. ${ }^{132}$ They argue that there has now occurred an "end to the carve-out for private law." 133 They cite a few examples. ${ }^{134}$

However, cases decided in the lower courts post-Medellin involving reliance on a treaty-based right against a private party reveal that the impact of Medellin in that realm is slight. Cases involving self-execution in treaties of friendship, commerce, and navigation, and in a major treaty on international sale of goods appear unaffected. Under the U.S.-Japan Treaty of Friendship, Commerce, and Navigation, a treaty not implemented by congressional legislation, Japanese companies have the right to hire executive personnel of their own choosing and routinely win cases filed by Anglo-Americans who claim discrimination for being passed over. ${ }^{135}$ This Treaty has no "statement" like that demanded by the Court in Medellín.

Medellin has been disregarded in cases arising under the Convention on the International Sale of Goods (CISG), which regulates the sale of goods between private parties located in different countries. ${ }^{136}$ The CISG has not been implemented by congressional legislation. Its articles prescribing rights and obligations for parties to a covered sale are considered self-executing. ${ }^{137}$ It is applied as self-

132. Hathaway, McElroy \& Solow, supra note 130, at 71.

133. Id. at 73 .

134. See id. at $73-76$.

135. See Trisko v. Nitto Kohki, No. 10-CV000281, 2011 WL 4345837 (N.D. Ill. Sept. 13 2011); Weber v. FujiFilm Med. Sys., Inc., 854 F. Supp. 2d 219 (D. Conn. 2012).

136. See Convention on the International Sale of Goods, Apr. 11, 1980, 1489 U.N.T.S. 3.

137. Franco Ferrari, Contracts for the International Sale of Goods: Applicability and Applications of the 1980 United Nations Sales Convention 32-33 (2012). 
executing by U.S. courts, even though its text contains no statement calling for self-execution. ${ }^{138}$

The Medellin case generated speculation as to whether the selfexecuting character of the CISG might be revisited. ${ }^{139}$ However, the courts have continued to apply the CISG. In a 2011 case, the Eighth Circuit applied the CISG to a suit between two private parties, without commenting on why it applied. ${ }^{140}$ The Southern District of New York, applying the CISG in another 2011 case, did mention the fact that it considered the CISG to be self-executing: "The CISG is a self-executing treaty, binding on all signatory nations, that creates a private right of action in federal court under federal law. As a treaty, the CISG is a source of federal law." ${ }^{141}$ The court did not mention Medellin as imposing any requirements that might negate the selfexecuting character of CISG obligations.

In a 2012 case in which the plaintiff argued that the CISG applied to a contract, another U.S. district court said, "The Court agrees that because the United States and China are both CISG signatories, the CISG governs the contracts." ${ }^{142}$ The court said nothing further about application of the CISG. ${ }^{143}$ Again in 2012, still another U.S. district court, when implementing CISG, characterized it as self-executing. ${ }^{144}$ In support, the court did cite Medellin, but only the passages in Medellin that refer to Foster $\&$ Elam for the proposition that some treaty provisions are self-executing. ${ }^{145}$ The district court did not cite the pages in Medellin that require a statement that suggests selfexecution.

The courts appear to be ignoring the prescriptions of Medellin in regard to one category of treaty that provides individual rights against the government, namely, treaties aimed at preventing double taxation of income by more than one state. Provisions in such treaties that protect an individual from paying tax twice on the same income

138. See Vázquez, Treaties as Law of the Land, supra note 72, at 637 n.175.

139. See Mark Cantora, The CISG After Medellin v. Texas: Do U.S. Businesses Have It? Do They Want It?, 8 J. InT'L Business \& LAW 111, $112(2009)$.

140. Dingxi Longhai Dairy, Ltd. v. Becwood Tech. Grp., 635 F.3d 1106, 1107 (8th Cir. 2011).

141. Hanwha Corp. v. Cedar Petrochemicals, Inc., 760 F. Supp. 2d 426, 430 (S.D.N.Y. 2011) (internal citation omitted).

142. Maxxsonics USA, Inc. v. Fengshun Peiying Electro Acoustic Co., No. 10-C-1174, 2012 WL 962698, at*4 (N.D. Ill. Mar. 21, 2012).

143. See id.

144. Beth Schiffer Fine Photographic Arts, Inc. v. Colex Imaging, Inc., No. 10-05321, 2012 WL 2835543, at *7 (D.N.J. Mar. 19, 2012).

145. See id. 
are regarded as self-executing. ${ }^{146}$ Such treaties typically lack specific language calling for self-execution, yet taxpayers have been allowed to rely on provisions that would benefit them. In a 2009 case in which a taxpayer relied on a taxation treaty with Canada, ${ }^{147}$ the U.S. Court of Appeals entertained the taxpayer's argument to determine whether the treaty provision resulted in the redress sought, without referring to the doctrine of self-execution or to Medellin. ${ }^{148}$ In a 2012 case, the U.S. Tax Court referred to the provisions of a tax treaty with France to determine whether the taxpayer was exempt from taxation in the United States on certain income. ${ }^{149}$

Another aspect of Medellin that is being ignored in private law cases is the Court's view that the presence of an enforcement mechanism negates self-execution. The Japan-U.S. FCN treaty, as noted, contains such a mechanism, namely, a clause allowing suit in the ICJ where either Japan or the United States considers the other to be in violation. ${ }^{150}$ In a 2011 U.S. district court case, an AngloAmerican was fired by a Japanese company operating in the United States. ${ }^{151}$ He sued, alleging discrimination in violation of U.S. legislation. The court found his allegations ill-founded but said that even if they were, they would be barred by provisions in the JapanU.S. Friendship, Commerce, and Navigation Treaty that afford complete freedom in selection of executive staff. ${ }^{152}$ The Court did not mention Medellín. In a 2012 case involving a similar issue, another U.S. district court likewise allowed a Japanese employer to rely on the Japan-U.S. FCN treaty. ${ }^{153}$ As noted, the provision of that Treaty on executive hiring continues to be implemented. The lower courts in post-Medellin cases simply do not mention the enforcement mechanism or the Court's mention of enforcement mechanisms as a factor negating self-execution.

The U.S. Supreme Court in Medellin, to be sure, mentioned FCN treaties, as examples of treaties the Court in the past had held to be

146. See Wu, supra note 64 , at 643 .

147. Convention with Respect to Taxes on Income and on Capital, U.S.Canada, Sept. 26, 1980, T.I.A.S. No. 11087.

148. See Jamieson v. Comm'r, 584 F.3d 1074, 1075 (D.C. Cir. 2009).

149. See Letourneau v. Comm'r, 103 T.C.M. (CCH) 1229 (T.C. 2012).

150. Treaty of Friendship, Commerce and Navigation, supra note 79, art. $24(2)$.

151. Trisko v. Nitto Kohki, No. 10-CV000281, 2011 WL 4345837, at *1 (N.D. Ill. Sept. 13, 2011)

152. Id.

153. See Weber v. FujiFilm Med. Sys., Inc., 854 F. Supp. 2d 219, 230 (D. Conn. 2012). 
self-executing in certain of their provisions. ${ }^{154}$ The Court did not seem to criticize those past decisions. It said that the FCN treaties were held to be self-executing based on their language. ${ }^{155}$ But if one examines those FCN treaties, one finds nothing like the "statement" the Court said would be necessary to hold a treaty provision selfexecuting. And past FCN treaties have had enforcement provisions; a feature that the Court in Medellín says disqualifies a treaty's provision as self-executing. Those past FCN treaties thus do not meet the new requirements on two grounds. By the Court's reasoning in Medellin, an FCN treaty that simply provides, as do most, for certain rights for foreign nationals in the territory of the other contracting party, and which, as many do, provide an enforcement mechanism, might fail the Court's test for self-execution.

\section{CONCLUSION}

Medellin involved the hardest possible situation for self-execution, since what was at issue was not a statement one could find in the treaty, but a decision made by a judicial organ created by a treaty. A narrow reading of the holding in Medellin is that that it relates solely to the self-executing character of U.N. Charter Article 94, or at least to treaty provisions that require compliance with the decision of a treaty-created judicial organ. ${ }^{156}$ The Court's apparent requirement of a "statement" is ambiguous, particularly when taken together with the Court's apparent approval of a self-execution finding in prior cases involving treaties lacking such a "statement." If the Court meant to overrule its prior cases, it could have done so. It did not. It purported to preserve its prior case law. Lower courts, even those that do not simply ignore Medellín, may be able to resist suggestions that are likely to be made by counsel that Medellín requires far-reaching restrictions on self-execution.

154. See Medellin v. Texas, 552 U.S. 491, 521 (2008).

155. Id.

156. See Curtis Bradley, Intent, Presumptions, and Non-Self-executing Treaties, 102 Am. J. INT'L L. 540 (2008) (noting this factor though not quite suggesting that the decision is limited to this factual circumstance). 